\title{
Competition and Cooperation in Hospital Provision in Middlesbrough, 1918-1948
}

\section{BARRY M DOYLE*}

The history of the English hospital in the first half of the twentieth century has been the focus of considerable debate from the very beginning of the National Health Service. ${ }^{1}$ In the early post-war years a powerful image was built up of the mix of voluntary and local state provision as one characterized by restricted access, over-weaning charity, stigma and inadequate coverage. Hospital services were undemocratic, inefficient, underfinanced and uncoordinated, staggering from one crisis to another yet unable to help themselves due to professional and political rivalries, which prevented rationalization. ${ }^{2}$ However, recent years have seen the development of a more thorough hospital history for the interwar period which provides an increasingly nuanced approach to the pre-NHS system. Initial revisions were provided by Steven Cherry, whose work on voluntary sector funding ${ }^{3}$ began to suggest a less pessimistic story about the situation in the 1930s than that of Brian Abel-Smith and Robert Pinker or even Charles Webster. ${ }^{4}$ The changes within the voluntary sector have been further examined by John Mohan, Martin Gorsky and Martin Powell, ${ }^{5}$ whilst finance and especially contributory schemes have been investigated by Mohan, Gorsky and Tim Willis. ${ }^{6}$ This work confirmed Cherry's evidence of considerable advance

\section{(C) Barry M Doyle 2007}

*Barry M Doyle, BA, PhD, Assistant Dean (Research), School of Social Sciences and Law, University of Teesside, Middlesbrough, TS1 3BA, UK.

The research for this paper was conducted with financial support from the Wellcome Trust and the History Research Group at the University of Teesside. I am indebted to Robina Weeds for carrying out the research with such assiduousness, imagination and enthusiasm. Early versions of the article were presented to various international conferences and to The Wellcome Trust Centre for the History of Medicine at University College London seminar, 'Revisiting the Hospital', February, 2006.

${ }^{1}$ R M Titmuss, Problems of social policy, London, Longman, 1950.

${ }^{2}$ For a modern summary of this view, see $\mathrm{N}$ Timmins, The five giants: a biography of the welfare state, London, Harper Collins, 1995.

${ }^{3} \mathrm{~S}$ Cherry, 'Beyond national health insurance. The voluntary hospitals and hospital contributory schemes: a regional study', Soc. Hist. Med., 1992, 5: 455-82; idem, 'Accountability, entitlement, and control issues and voluntary hospital funding c.1860-1939', Soc. Hist.Med., 1996, 9: 215-33; idem, 'Before the National
Health Service: financing the voluntary hospitals, 1900-1939', Econ. Hist. Rev., 1997, 50: 305-26.

${ }^{4}$ B Abel-Smith, The hospitals 1800-1948: a study in social administration in England and Wales, London, Heinemann, 1964; R Pinker, English hospital statistics, 1861-1938, London, Heinemann, 1966; $\mathrm{C}$ Webster, The health services since the war: problems of health care, London, HMSO, 1988.

${ }^{5}$ In particular, M Gorsky, J Mohan and M Powell, 'British voluntary hospitals, 1871-1938: the geography of provision and utilization', J. Hist. Geog., 1999, 25: 463-82; M Gorsky and J Mohan, 'London's voluntary hospitals in the interwar period: growth, transformation or crisis?', Nonprofit and Voluntary Sector Quarterly, 2001, 30: 247-75; M Gorsky, J Mohan, and M Powell, 'The financial health of voluntary hospitals in interwar Britain', Economic History Review, 2002, 55: 533-57; M Gorsky, M Powell and J Mohan, 'British voluntary hospitals and the public sphere: contribution and participation before the National Health Service', in S Sturdy (ed.), Medicine, health and the public sphere in Britain, 1600-2000, London, Routledge, 2002, pp. 123-44.

${ }^{6} \mathrm{M}$ Gorsky, J Mohan and T Willis, 'Hospital contributory schemes and the NHS debates 1937-46: the rejection of social insurance in the British welfare state?', Twentieth Cent. Br. Hist., 2005, 16: 170-92. 


\section{Barry M Doyle}

for voluntary hospitals between the wars - the number of beds in non-state hospitals more than doubled, and income from contributory schemes increased substantially, providing access by right to hospital treatment for a growing section of the population. ${ }^{7}$ Yet there is also a less optimistic tone to this work which reinforces the sense of unevenness in provision, especially in poorer, medium sized towns and in rural areas, particularly in the north. ${ }^{8}$ Furthermore, there is a recognition that the contributory schemes were coming under pressure as a result of their success, creating a demand for treatment that the hospitals could not meet and for which the schemes were not charging sufficiently large contributions. ${ }^{9}$ Importantly, however, this work has provided a broadening of our understanding of the pattern of national provision (much early assessment of the health of the pre-war voluntary sector was based on the situation in London) and has begun the process of uncovering the local variation and some of the underlying causes of that unevenness.

There has also been growing interest in the development of the municipal sector between the wars. Much emphasis in discussions of the establishment of the NHS has focused around the division between Herbert Morrison's vision of a municipally controlled state hospital service (drawing on established national Labour party policy) and Bevan's nationalization solution. ${ }^{10}$ Some historians have looked to the municipal system as the path not taken, seeing in local authority control a democratic alternative to the statist centralization which came to characterize the NHS. ${ }^{11}$ Others, like Charles Webster, have focused on the failure of the municipal sector to advance towards an integrated system, ${ }^{12}$ whilst researchers such as Mohan have explored the way in which the poverty of many local authorities between the wars limited their ability to meet local demand for hospital services. ${ }^{13}$ Yet much of this discussion has taken place with only limited knowledge of the actual performance of the municipal sector between the wars and its capacity and capability to deliver the type of service its advocates desired. Progress is being made in this field with major surveys of county borough provision across England and Wales being undertaken by Alysa Levene, Martin Powell and John Stewart. ${ }^{14}$ Powell's early work in this field began the process of indicating the strengths and weaknesses of municipal provision, ${ }^{15}$ whilst Stewart was highly influential in expanding understanding of the situation in London and the position of the key advocates for municipal control in the Socialist Medical Association. ${ }^{16}$

\footnotetext{
${ }^{7}$ Gorsky, Mohan and Powell, 'Geography of provision', op. cit., note 5 above; idem, 'Public sphere', op. cit., note 5 above.

${ }^{8}$ Gorsky, Mohan and Powell, 'Geography of provision', op. cit., note 5 above, pp. 472-4; J Mohan, Planning, markets and hospitals, London, Routledge, 2002.

${ }^{9}$ See, for example, Gorsky and Mohan, 'London's voluntary hospitals', op. cit., note 5 above, for the situation in the capital.

${ }^{10} \mathrm{C}$ Webster, The National Health Service: a political history, 2nd ed., Oxford University Press, 2002, pp. 15-25; H Jones, Health and society in twentieth-century Britain, Harlow, Longman, 1994, pp. 119-25, 139-40; A Hardy, Health and medicine in Britain since 1860, Basingstoke, Palgrave Macmillan, 2001, pp. 140-2.
}

\footnotetext{
${ }^{11}$ See, for example, V Berridge, Health and society in Britain since 1939, Cambridge University Press, 1999, pp. 14-15.

${ }^{12}$ Webster, Political history, op. cit., note 10 above, pp. 3-5.

${ }^{13}$ Mohan, Planning, op. cit., note 8 above, pp. 37-44.

${ }^{14}$ A Levene, M Powell, and J Stewart, 'Patterns of municipal health expenditure in interwar England and Wales', Bull. Hist. Med., 2004, 78: 635-69; A Levene, M Powell, and J Stewart, 'The development of municipal hospital care in English county boroughs in the 1930s', Med. Hist., 2006, 50: 3-27.

${ }^{15} \mathrm{M}$ Powell, 'An expanding service: municipal acute medicine in the 1930s', Twentieth Cent.Br. Hist., 1997, 8: 334-57.

${ }^{16}$ J Stewart, " "For a healthy London": the Socialist Medical Association and the London County Council in
} 


\section{Hospital Provision in Middlesbrough, 1918-1948}

As with the research of Mohan and Gorsky, they are beginning to provide a macro picture of municipal provision with local examples and some drilling down, providing evidence of and tentative reasons for local variation.

These accounts have been shaped by a more traditional health policy literature which has tended to focus on the failures of the pre-1948 system. ${ }^{17}$ Drawing heavily on high political debates, on Ministry of Health sources and on the evidence collected by the various commissions and surveys conducted by both government and pressure groups between 1921 and 1945, such works draw a bleak account of financial crisis, the collapse of traditional charity and the weakness of local authorities. ${ }^{18}$ In particular, they castigate pre-NHS hospital providers for their inability to meet the expectations and ambitions of Lord Cave, who advocated joint working as early as 1921, or Lord Dawson, who promoted the idea of central clearing houses for patients, unified clinics and rational resource allocation, ${ }^{19}$ or PEP who captured the policy mood of the late 1930s in advocating planning. ${ }^{20}$ Yet such works take a top-down approach to the development of hospital provision and are often sympathetic to the views put forward by advocates of rationalization. These accounts support wider debates about the nature of service provision in early-twentiethcentury Britain, in particular, Geoffrey Finlayson's concepts of the "mixed economy" of welfare and the "moving frontier". 21 Finlayson challenged a teleological view of the advance of welfare provision by highlighting both the presence of a multiplicity of providers in the inter-war period and the fact that the dominance of any particular group in the mix could change over time. Clearly the contested nature of this mixed economy between the wars is in need of closer examination, especially at the local level.

Yet there have been few local studies of voluntary or state hospital provision in this period and even fewer that address the interaction of public and voluntary. In fact, much of the research which does exist, continues to highlight the enduring failure of municipal and charitable sectors to agree on priorities and develop efficient systems for all. ${ }^{22}$ Studies of London have tended to present a sharp division between the two sectors, which from 1934 were divided ideologically as well as structurally. ${ }^{23}$ London's difference is increasingly accepted by historians whose provincial studies attempt to piece together the more common experience for populations outside the capital. John Pickstone's study of Lancashire provided a model for exploring the development of urban hospital services, especially the

the 1930s', Med. Hist., 1997, 41: 417-36; idem, 'The battle for health' : a political history of the Socialist Medical Association, 1930-1951, Aldershot, Ashgate, 1999.

${ }^{17}$ Webster, Political history, op. cit., note 10 above; Jones, op. cit., note 10 above; V Berridge, 'Health and medicine, 1750-1950', in F M L Thompson (ed.), Cambridge social history of Britain, 1750-1950: vol. III, Cambridge University Press, 1990, pp. 171-242;

${ }^{18}$ Mohan, Planning, op. cit., note 8 above, chs $2-3$, for a regional example.

${ }^{19}$ Consultative Council on Medical and Allied Services, Interim report on the future provision of medical and allied services (Dawson Report), Cmnd 693, London, HMSO, 1920. See Mohan, Planning, op. cit., note 8 above, for discussion.

\footnotetext{
${ }^{20}$ Political and Economic Planning (PEP), Report on the British health services, London, PEP, 1937.

${ }^{21}$ Geoffrey Finlayson, Citizen, state and social welfare in Britain, 1830-1990, Oxford, Clarendon Press, 1994.

${ }^{22} \mathrm{C}$ Webster, 'Conflict and consensus: explaining the British health service', Twentieth Cent. Br. Hist., 1990, 1: 115-51; Mohan, Planning, op. cit., note 8 above.

${ }^{23}$ For the nineteenth-century origins, see $\mathrm{K}$ Waddington, Charity and the London hospitals, 1850-1898, Woodbridge, Boydell Press, 2000; Stewart, " "For a healthy London" ', op. cit., note 16 above; G Rivett, The development of the London hospital system, 1823-1982, London, King's Hospital Fund for London, 1986.
} 


\section{Barry M Doyle}

impact of a big city with a large teaching hospital, ${ }^{24}$ whilst Daniel Fox's broader study of inter-war institutional expansion introduced the concept of hierarchical regionalism. In this he suggested that hospital providers gave increasing support to the idea of integrated services and in particular supported their organization around a central medical school. ${ }^{25}$ Mohan, in his study of north-east England in the 1930s, is highly sceptical about the existence of any unity between municipal and voluntary providers or moves towards efficient division of services, arguing that poverty, parochialism and patchiness all led to inadequate provision everywhere except Newcastle. He looks only briefly at the development of joint public/private working before 1939 (although he does address the joint municipal TB sanatorium in Middlesbrough), ${ }^{26}$ producing a largely side-by-side account of the institutional provision in Tyneside and County Durham (his work on Middlesbrough drawing entirely on secondary sources). ${ }^{27}$ More optimistic accounts of developing systems have been provided for individual towns such as Bristol, Manchester and Birmingham where medical schools clearly were very influential in promoting amalgamation and integrated services. ${ }^{28}$ Gorsky's and Pickstone's work highlights the central importance of medical schools in promoting and facilitating integration through their independence, income, powers of patronage and prestige, and by their ability to offer a politically neutral focus for reform around which voluntary and state providers could unite. ${ }^{29}$

The evidence and the case for integration is more ambiguous for towns without medical schools. Integration seems to have been slower in Leicester, though Welshman's evidence is rather scant on voluntary-municipal relations in a book concerned primarily with the work of the municipal officers. ${ }^{30}$ Cherry's account of Norwich also seems to implythough not state - that the absence of a teaching hospital in the city affected the form hospital provision took. His study does not explore joint working at all, providing descriptions of the municipal and voluntary sectors along with some analysis of state and general practitioner services. ${ }^{31}$ Similarly, Willis's assessment of hospitals in Sheffield concentrates on examining the growing unity within the voluntary sector on the one hand and the municipal providers on the other but overlooks potential for joint working between the two, which may have been inhibited by the growing ideological divide between the voluntary hospitals and the socialist-run municipal sector. ${ }^{32}$ Thus, it remains that little is known

\footnotetext{
${ }^{24} \mathrm{~J}$ V Pickstone, Medicine and industrial society: a history of hospital development in Manchester and its region 1752-1946, Manchester University Press, 1985.

${ }^{25} \mathrm{D}$ Fox, Health policies, health politics: the British and American experience, 1911-1965, Princeton University Press, 1986.

${ }^{26} \mathrm{~J}$ Mohan, 'The neglected roots of regionalism? The Commissioners for the Special Areas and grants to hospital services in the 1930s', Soc. Hist. Med., 1997, 10: $243-62$. and 3 .

${ }^{27}$ Mohan, Planning, op. cit., note 8 above, chs 2

${ }^{28}$ M Gorsky, " "For the treatment of sick persons of all classes": the transformation of Bristol's hospital services, 1918-1939', in P Wardley (ed.), Bristol historical resource $C D$-ROM, Bristol, 2000, for Bristol
}

and Birmingham, and Pickstone, op. cit., note 24 above, pp. 251-67, for Manchester.

${ }^{29}$ This would seem to be the case in Bristol,

Manchester, Aberdeen and Birmingham by the 1940s. Gorsky, 'Bristol', op. cit., note 28 above, section 5.3, 'The revival of integration in the 1930s'; Pickstone, op. cit., note 24 above, p. 267; and M Gorsky,

" "Threshold of a new era": the development of an integrated hospital system in north-east Scotland, 1900-39', Soc. Hist. Med., 2004, 17: 247-67.

${ }^{30} \mathrm{~J}$ Welshman, Municipal medicine: public health in twentieth-century Britain, Oxford, Peter Lang, 2000.

${ }^{31} \mathrm{~S}$ Cherry, 'Medical care since 1750', in

C Rawcliffe and R Wilson (eds), Norwich since 1550, London, Hambledon, 2004, pp. 271-94.

${ }^{32} \mathrm{~T}$ Willis, 'Politics, ideology and the governance of health care in Sheffield before the NHS', 
about local trends and the extent to which urban hospital systems were developing prior to 1946, especially in towns without a medical school.

This article addresses a number of questions raised by this literature. It examines the relations between the various hospital providers in Middlesbrough to ascertain the extent to which moves towards cooperation and integration were taking place; the speed at which they occurred and which forces were driving cooperation. It will also illuminate the barriers to closer relations and, inter alia, investigate the issues of politics, parochialism, voluntary sector intransigence and municipal ineffectiveness raised by both the national and other local studies. This will then permit an analysis of the degree to which Middlesbrough had developed a rationalized, efficient hospital system by 1945 and especially the distance travelled since 1918.

This research is predominantly based in local sources-hospital records, local authority records, local press coverage-rather than the Ministry of Health material gathered by outside inspectors. Furthermore, it is less concerned with the impact of national policy initiatives, especially debates generated by think tanks and pressure groups like PEP and Nuffield, than with how local actors and institutions negotiated the transition from individual to corporate activity and the everyday issues that shaped their responses. Nor will it focus very closely on the Emergency Medical Service (EMS), concentrating instead on wartime continuity with pre-war developments, especially arrangements between the voluntary and municipal general hospitals which seem to have had little to do with the workings of the EMS. Similarly though the wartime hospital survey has informed this study and previous work by the author, ${ }^{33}$ the snapshot effect it portrays has tended to distort our understanding of development and change at the local level. In all these respects, this study will move away from both the conventional approach to inter-war studies of integration and the types of source base they have used to provide instead a "bottom up" view of change. It will address these questions through a case study of the northern industrial town of Middlesbrough, ${ }^{34}$ first outlining the development of hospitals in the town before exploring the creation of a municipal system, examining unity in the voluntary sector and finally assessing the extent to which the two sectors were coming together before 1945 . Martin Gorsky's evidence from Bristol ${ }^{35}$ will be used for comparisons to illuminate the extent to which the experience in Middlesbrough can be seen as representative, at least, of a type of urban hospital service.

\section{The Health Problems of Middlesbrough}

Middlesbrough was a creation of the nineteenth century. Established in the 1830s as a port for the export of South Durham coal, by the middle of the 1850 s coal exports had

in R J Morris and R H Trainor (eds), Urban governance: Britain and beyond since 1750, Aldershot, Ashgate, 2000, pp. 128-49.

${ }^{33}$ Ministry of Health [H Lett and A E Quine], Hospital survey: the hospital services of the North-Eastern area, London, HMSO, 1946; B Doyle, A history of hospitals in Middlesbrough,

Middlesbrough, South Tees NHS Hospitals Trust, 2002.

\footnotetext{
${ }^{34}$ The issue has received some attention from J Mansfield, 'From competition to co-operation: co-ordination of acute hospital services in Middlesbrough, 1920-1950', MA Dissertation, Teesside Polytechnic, 1991; and Mohan, Planning, op. cit., note 8 above, especially pp. 54,58 , which draw heavily on Mansfield.

${ }^{35}$ Gorsky, 'Bristol', op. cit., note 28 above.
} 


\section{Barry M Doyle}

declined, to be replaced by a booming iron industry based on the discovery of local ore deposits. Population growth in the course of the nineteenth century was remarkable, and between 1841 and 1881 the population increased more than tenfold so that by the early twentieth century the village of less than fifty in 1801 had become a town of 100,000 inhabitants. ${ }^{36}$ Both the rapid growth of the population and the shift to metal making had a profound effect on the health of the population of Middlesbrough. The demand for housing in the nineteenth century led to rapidly declining standards, as courts and yards filled in the spaces behind the broad streets of the original plan. Such conditions encouraged the spread of contagious diseases, including cholera, typhoid, scarlet fever and tuberculosis. ${ }^{37}$ Yet health was also increasingly threatened by other aspects of the environment. Damp was a major characteristic of the housing, exacerbated in many parts of the town by the tendency to flooding. ${ }^{38}$ Smoke from ironworks combined with heavily hanging moist air to produce smog for half the year, which was believed to have contributed to the prevalence of an infectious form of pneumonia known as Middlesbrough Pneumonia. ${ }^{39}$ But local industry did not just damage health through its polluting effects, it also impinged extensively on the workers in two ways: through the deleterious impact of the working conditions; and the dangers attached to the processes. Writing in 1907, Lady Florence Bell observed of conditions in the iron industry that:

One is apt to be surprised at first, considering that it is presumably the strong and stalwart who have taken up this work, to find how many of the workmen are more or less ailing in different ways; but we cease to be surprised when we realize how apt the conditions are to tell upon the health even of the strongest, and how many of the men engaged in it are spent by the time they are fifty ... They are exposed to extremes of temperature, being liable to become violently heated when at their work, and violently chilled when they move away from it. They come home tired, their vitality lowered, their clothes often wringing wet. They are constantly inhaling noxious fumes ...

And she continued:

The men also suffer from rheumatism, from asthma, from pneumonia (often of a dangerous and virulent kind), from feverish attacks, from blood-poisoning in one form or another caused by some scratch on the surface of the skin when handling hot iron, from affections of the eyes due to exposure to dust, to glare, and to noxious vapours. Consumption is also frequent. It happens over

\footnotetext{
${ }^{36}$ A Briggs, 'Middlesbrough: the growth of a new community', in idem, Victorian cities, Harmondsworth, Penguin, 1968; A J Pollard (ed.), Middlesbrough: town and community, 1830-1950, Thrupp, Sutton Publishing, 1996; G A North, Teesside's economic heritage, Middlesbrough, Cleveland County Council, 1975; W Lillie, The history of Middlesbrough: an illustration of the evolution of English industry, Middlesbrough Borough Council, 1968; J W Leonard, 'Urban development and population growth in Middlesbrough 1831-1871', $\mathrm{PhD}$ thesis, University of York, 1975.

${ }^{37}$ L Polley, 'Housing the community, 1830-1914', in Pollard (ed.), op. cit., note 36 above, pp. 153-72; Max Lock (ed.), Middlesbrough survey and plan, Middlesbrough Corporation, 1946.
}

\footnotetext{
${ }^{38}$ W Ranger, Report to the General Board of Health ... Middlesbrough, London, Eyre and Spottiswoode, 1854; Lady F Bell, At the works: a study of a manufacturing town, first pub., London, 1907, repub. Middlesbrough, University of Teesside, 1997, ch. 1.

${ }^{39}$ Dr Ballard, 'Report upon epidemic malady prevalent in Middlesbrough and its neighbourhood, the most obvious character of the disease being pleuro-pneumonia', Reports of the Medical Officer of the Local Government Board, App. A, No.18 C.5813,1888, pp. 163-333; J Watkin Edwards, 'Industrial diseases of iron and steel works in Middlesbrough', Iron and Coal Trades Review, 11 Aug. 1916, 93: 153-4; J Blanco-White, 'Atmospheric pollution in the county borough of Middlesbrough',
} 


\section{Hospital Provision in Middlesbrough, 1918-1948}

and over again that, when it has been possible to arrest the disease by sending the man away to some sanatorium, he has fallen back as soon as he has returned to his unhealthy surroundings. ${ }^{40}$

Accidents were commonplace, with burns, eye injuries and crushing most frequent. Elsewhere in the town, the extensive railway works, the docks and the building industry all presented substantial physical danger to the workers, whilst the overall environment of industrial effluent, transport and menacing works posed a constant threat to the health of the women and children of the town. ${ }^{41}$

Yet, for many, the dangers of the vibrant industrial town were preferable to the health implications of the unemployment and poverty that blighted Middlesbrough between the wars. This was an unusual situation for the population, as for most of the nineteenth century Middlesbrough's workers received good and regular wages, more often interrupted by illness and accident than by unemployment or short time. ${ }^{42}$ Between the wars, however, the experience was different, with long-term unemployment affecting almost half the male population, substantially reducing family incomes for all but the poorest. Death rates in the poorest areas (like St Hilda's and Newport) remained stubbornly high, as did the incidence of and deaths from TB and other respiratory diseases, which some, at least, put down to poverty and overcrowding caused by unemployment. ${ }^{43}$

Last amongst Middlesbrough's health problems were high birth and infant mortality rates. The prevalence of young men in the population and the absence of opportunities for work for women, along with the relatively early age at which men earned above average wages meant that couples, especially girls, married very young. ${ }^{44}$ As a result they had large families coupled to very high infant mortality-amongst the highest anywhere in the country. Undoubtedly poor housing, especially the persistence of the privy pan system into the 1920s, contributed to the infant death toll, whilst poverty and over-crowding also played a part. ${ }^{45}$ Rates did fall, especially after the mid-1920s and were slowly converging with national figures by the 1940 s. $^{46}$

\section{Hospital Services in Middlesbrough}

Together, these factors created a demand for both specific and general acute hospital services, which was met by a range of responses from the local political and charitable population, who assembled one of the most extensive hospital services outside a major city

$\overline{\text { in Lock }}$ (ed.), op. cit., note 37 above, pp. 345-52; A-K Woebse, 'The environmental history of Middlesbrough', Cleveland History, 1995, 69: 2-19.

${ }^{40}$ Bell, op. cit., note 38 above, pp. 90-1.

${ }^{41}$ North, op. cit., note 36 above; Bell, op. cit., note 38 above; D Taylor, 'The infant Hercules and the Augean Stables: a century of economic and social development in Middlesbrough, c.1840-1939', in Pollard (ed.), op. cit., note 36 above, pp. 53-80.

${ }^{42}$ A A Hall, 'Wages, earnings and real earnings in Teesside: a reassessment of the ameliorist interpretation of living standards in Britain, 1870-1914', Int. Rev. Soc. Hist., 1981, 26: 202-19; J J Turner, 'The frontier revisited: thrift and fellowship in the new industrial town, c.1840-1914', in Pollard (ed.), op. cit., note 36 above, pp. 81-102; Bell, op. cit., note 38 above, pp. 26-7, 48.

${ }^{43} \mathrm{~K}$ Nicholas, Social effects of unemployment on Teesside, 1919-1939, Manchester University Press, 1986; and G Rowntree, 'Health services in Middlesbrough', in Lock (ed.), op. cit., note 37 above, pp. 323-5.

${ }^{44}$ Bell, op. cit., note 38 above, pp. 78-82.

${ }^{45}$ Taylor, op. cit., note 41 above, pp. 74-5; Polley, op. cit., note 37 above; J Albery, 'Housing', in Lock (ed.), op. cit., note 37 above, pp. $185-236$.

${ }^{46}$ Taylor, op. cit., note 41 above, pp. 78-9. 


\section{Barry M Doyle}

anywhere in England. Indeed, Middlesbrough, with Bristol, was in the top ten providers of voluntary hospital beds in 1911, challenging the usual characterization of new industrial towns as deficient in hospital services. ${ }^{47}$ This is particularly surprising for, as a new town of the nineteenth century, Middlesbrough lacked both an old established elite to lead and fund charitable organizations - as was the case in cities like Bristol, Norwich or Leeds - and the historic borough privileges and property along with a wide rates base which allowed some towns to avoid either high rates or municipal trading. In response, the council took control of a number of utilities before the end of the nineteenth century to help meet the cost of an expanding range of services. ${ }^{48}$ This investment was matched by an extensive network of self-help organizations run by and for the workers, including friendly societies, benevolent societies and sick clubs, some operating with the employers, but many entirely in the hands of the workers. ${ }^{49}$

By 1918, Middlesbrough had six hospitals: two voluntary institutions-North Ormesby Hospital (NOH, 1861) and North Riding Infirmary (NRI, 1864) — the Poor Law Infirmary (1878), which changed its name to Holgate in 1915, and its separate children's hospital, and the two municipal hospitals for infectious diseases, West Lane (1872) and Hemlington (1895). Over the next twenty years all of these hospitals were enlarged and upgraded whilst three new institutions were added, a municipal maternity hospital (1920), a voluntary/ private bequest GP hospital (1926) and a TB sanatorium (1932/45). As a result, by 1935 Middlesbrough could offer around 600 general beds as well as approximately 250 beds for infectious diseases, including various forms of TB provision, 80 for children and 50 maternity. ${ }^{50}$ As with many larger county boroughs in 1918, this hospital provision was in the hands of the voluntary sector, the Poor Law and the borough council. Furthermore, the voluntary sector was divided between three separate providers who competed for patients, prestige and, most importantly, funding, ${ }^{51}$ whilst the state sector was playing an increasing role in general hospital provision. ${ }^{52}$

Each of the hospitals had its own patient base, which was more or less accepted in the 1920s. The NOH and the NRI drew most of their patients from employed working men, their wives and children, who contributed to the hospitals through work place schemes. ${ }^{53}$

\footnotetext{
${ }^{47}$ Gorsky, Mohan and Powell, 'Geography of provision', op. cit., note 5 above, Table 4, p. 472, pp. 473-4.

${ }^{48} \mathrm{~B}$ M Doyle, 'The changing functions of urban government: councillors, officials and pressure groups', in M Daunton (ed.), The Cambridge urban history of Britain: volume 3, 1830-1950, Cambridge University Press, 2000, pp. 287-314; M Gorsky, Patterns of philanthropy: charity and society in nineteenth-century Bristol, London, Royal Historical Society, 1999; Cherry, op. cit., note 31 above.

${ }^{49}$ Turner, op. cit., note 42 above.

${ }^{50}$ Doyle, Hospitals, op. cit., note 33 above, pp. 9-13; G Stout, History of North Ormesby Hospital, Stokesley, Geoffrey Stout, 1989; J E Croker, 'Early hospital provision in Middlesbrough, 1860-1880', MA dissertation, Teesside Polytechnic, 1982; Mansfield, op. cit., note 34 above; G Stout and
}

R Blowers 'Smallpox hospitals in the Cleveland area of North Yorkshire, 1871-1946: notes from various sources', unpublished paper, Middlesbrough Reference Library, C362.11.

${ }^{51}$ For the roots of this competition in the Edwardian period, see B M Doyle, 'Voluntary hospitals in Edwardian Middlesbrough: A preliminary report', North East History, 2001, 34: 5-33. For similar competition in Bristol, see Gorsky, 'Bristol', op. cit., note 28 above, ch. 3 , 'Bristol's voluntary hospitals: a system in decline'.

${ }^{52}$ Holgate, the Poor Law Infirmary, began taking fee-paying patients in 1920, Minutes of Holgate hospital, 16 September 1920, Teesside Archives (hereafter TA), TA PU/M 1/28.

${ }^{53} \mathrm{~B}$ Doyle, 'Power and accountability in the voluntary hospitals of Middlesbrough, 1900-1948', in A Borsay and P Shapely (eds), Medicine, charity 


\section{Hospital Provision in Middlesbrough, 1918-1948}

Though initially most of the patients had been male-often the victims of accidents at work - by the First World War they were more evenly divided between men, women and children as the hospitals specialized in surgical cases, such as tonsils, along with broken bones, and an increasing amount of ophthalmic work. ${ }^{54}$ Funded largely by works' contribution schemes, the two main institutions covered over 70,000 working-class people in the Teesside area by the mid-1930s - though coverage varied with the state of the local economy. Thus the numbers treated rose through the 1920s, fell sharply in the early 1930s and climbed from 1934 onwards, with those eligible and treated peaking in the mid1940s. ${ }^{55}$ Although the Carter Bequest Hospital-a small GP staffed institution-treated mainly private patients, the NRI refused to take directly paying patients, and whilst the $\mathrm{NOH}$ did take them, they tended to be people not covered by the contributory schemes, such as older and single women. ${ }^{56}$ With their emphasis on short-term curative regimes, the voluntaries were highly selective in the patients they admitted - excluding those who could not be cured, along with infectious diseases, cancer, TB and maternity cases ${ }^{57}$ —and paring length of stay to a minimum (around seventeen days in the 1930s). ${ }^{58}$ However, they did provide an increasingly effective means of addressing the health problems associated with the town's industrial structure, their accident and emergency provision and surgical teams meeting most of the needs of the population.

The town's voluntary provision, though sharing many characteristics with other medium to large county boroughs, differed in important respects from Bristol. Although both had two main voluntary hospitals, Middlesbrough lacked the depth of medical practitioners to offer much in the way of specialist hospital services. Furthermore, Middlesbrough did not have a university nor, therefore, the potential for a medical school, whilst its need for accident and emergency and acute surgical provision may have been greater. However, the biggest difference was the funding system that, in the case of Middlesbrough, allowed income to rise to some extent with demand. Overall, large-scale workers' funding created a more democratic system of both admission and governance, and aided the voluntary hospitals of the town to negotiate falling charitable income and manpower more readily than in those cities such as Bristol, which relied on the time and money of the middle class. Moreover, as Bristol stuck closely to a combination of traditional voluntary income and the introduction of direct charges, this stifled the development of contributory schemes until the very end of the period. ${ }^{59}$

and mutual aid: the consumption of health and welfare, c.1550-1950, Aldershot, Ashgate, 2007, pp. 207-24.

${ }^{54}$ Ibid.

${ }^{55}$ B Doyle and R Nixon, 'Voluntary hospital finance in north-east England: the case of North Ormesby Hospital, Middlesbrough, 1900-1947' Cleveland History, 2001, 80: 4-18 on pp. 8-9; Mansfield, op. cit., note 34 above, p. 96.

56 'Patients must pay', North Eastern Daily Gazette (hereafter $N E D G$ ), 12 June 1931 for the Carter Bequest; NOH Council minutes, sub-committee, 29 May 1933, TA H/NOR/14; R Lewis, R Nixon and B Doyle, 'Health services in Middlesbrough: North Ormesby
Hospital 1900-1948', Unpublished report, Centre for Local Historical Research, Middlesbrough, 1999.

${ }^{57}$ North Ormesby Hospital annual report, 1933, p. 54; Statutes and rules for the government of the Infirmary, Middlesbrough for the North Riding of the County of York: revised 1902, Middlesbrough, 1902, pp. $17-18$.

${ }^{58}$ Lewis, Nixon and Doyle, op. cit., note 56 above, pp. 20-1; Mansfield, op. cit., note 34 above, p. 96.

${ }^{59}$ See Gorsky, 'Bristol', op. cit., note 28 above, section 3.3, 'Income in transition: from hierarchial charity to patients' contributions', for these differences. 


\section{Barry M Doyle}

Municipal (including Poor Law) provision largely existed to cover these deficiencies in the voluntary sector and meet the more specialized requirements of the population. This was not unusual. In most towns, voluntary hospitals restricted themselves to the acute, the curable and increasingly to the surgical, whilst state provision was about meeting minimal public health and safety needs and gradually incorporating a concern for the aged and chronically ill. ${ }^{60}$ The precise mix and quality of state services varied, with Middlesbrough again offering a level of provision closer to that of the older and wealthier county boroughs. Prior to 1929 hospital provision by the local state was divided between specialist public health accommodation, which was the responsibility of the municipal borough, and general provision for the very poor, which was in the hands of the Poor Law Guardians. ${ }^{61}$ The Guardians built a workhouse in the 1870 s, which included a separate Infirmary (PLI) with over 100 beds for men, women, some maternity cases (the only hospital maternity provision in the town until 1920) and a number of specialist conditions including skin diseases and VD. ${ }^{62}$ Treatment was basic, conditions austere and disciplined, staffing minimal and often inexperienced. Yet the separation of the PLI from the workhouse ensured that it could develop as an effective general hospital for those unable to gain entry to the voluntary institutions. ${ }^{63}$ By the early twentieth century it had grown in size, adopted the name Holgate, improved its staff and was gradually expanding into surgical and specialist treatment, especially maternity provision. ${ }^{64}$ In addition, it had acquired a separate children's hospital, called Broomlands, with fifty beds, though this was never a satisfactory establishment. ${ }^{65}$

By the 1920s Holgate was increasingly seen as a public general hospital with six consultants, and when the 1929 Local Government Act gave the county boroughs the opportunity to take over the local Poor Law infirmary provision by a process known as appropriation, Holgate was immediately appropriated, coming under municipal control in $1930 .{ }^{66}$ Its patient profile was very different to that of the voluntary hospitals, the majority of its inmates being casual labourers and seamen, women and the elderly, whilst a great many would appear to have been of Irish extraction. Their stays were long, their conditions mainly chronic, the death rate very high. ${ }^{67}$ Though not all were paupers, most were the residue from the voluntary sector, condemned to Holgate either because they could not contribute or because their illnesses could not be "materially improved". The profile did change a little in the 1920 s, especially with the opening up of the institution to paying

${ }^{60} \mathrm{~S}$ Cherry, Medical services and the hospitals in Britain, 1860-1939, Cambridge University Press, 1996, pp. 44-8, and Doyle, 'Urban government', op. cit., note 48 above.

${ }^{61}$ For the division of responsibilities, see Cherry, Medical services, op. cit., note 60 above, pp. 48-51, 61-3.

${ }^{62} \mathrm{~J} \mathrm{~J}$ Turner, 'Guisborough, Middlesbrough and Stockton Poor Law Union workhouses, 1837-c.1830: an introduction', unpublished, University of Leeds Dept. of Adult Education, n.d.; Doyle, Hospitals, op. cit., note 33 above, ch. 3 .

${ }^{63}$ Powell, 'Expanding service', op. cit., note 15 above, pp. 345-7.

\footnotetext{
${ }^{64}$ Information on the development and conditions at the hospital is drawn from the minutes of the Middlesbrough Board of Guardians, TA PU/M 1/3-41.

${ }^{65} \mathrm{P}$ Kitchen, Souvenir of the opening of the municipal children's hospital, Holgate, Middlesbrough Corporation, 1934. Middlesbrough Council Hospital Committee, 20 Nov. 1931, TA CB/M/H 13 .

${ }^{66}$ Middlesbrough Borough Council Minutes, TA CB/M/6/2/1930.

${ }^{67}$ For sample data from 1913, 1928 and 1930 (following appropriation), see TA PU/M 1/19, TA PU/M 1/39 and TA H/MG 1/1.
} 
patients and its growing popularity as a maternity hospital. Thus, in line with Powell's more generalized account, even before the 1929 Act, Middlesbrough's Poor Law Infirmary was already "expanding" its service, though as yet it could not challenge the voluntary hospitals in the area of acute treatment.

Borough provision before 1929 included West Lane Infectious Diseases Hospital, the first of its kind in the north-east of England, the rural smallpox sanatorium at Hemlingtonwhich also treated TB cases - and a substantial asylum, opened in 1898 to accommodate 500 patients. ${ }^{68}$ Together, these institutions (along with the PLI) reflected the local state's nineteenth-century function as the protector of public safety. ${ }^{69}$ They were exclusionary institutions designed to protect the population from physical and moral contagion. Yet in the twentieth century the borough expanded its services extensively under the leadership of the MOH, Dr Charles Dingle. Though the power and independence of MOsH varied widely across the country, those in county boroughs benefited from the general expansion and professionalization of municipal employees in the early twentieth century. As the volume and complexity of the work undertaken by council departments grew, officials acquired more decision-making authority, presenting politicians with carefully selected evidence and options. ${ }^{70}$ They could also concentrate administrative power by consolidating roles - as the $\mathrm{MOH}$ in Bristol did with the School Medical Officer post. ${ }^{71}$ Admittedly they did not always get their own way-C Killick Millard in Leicester and H Cooper Pattin in Norwich both faced council opposition to their slum clearance policies ${ }^{72}$ - but their central position in early-twentieth-century municipal policy warrants careful consideration of Dingle's role in Middlesbrough. Dingle not only managed to acquire the post of visiting surgeon and administrator to the PLI in the 1920s - thus effectively developing Holgate in line with his municipal agenda-he also oversaw the opening of a maternity hospital in 1920 and the gradual expansion of ID accommodation so that Middlesbrough became the de facto sub-regional centre for infectious diseases, adjacent boroughs buying beds in West Lane and Hemlington. ${ }^{73}$

Municipal provision developed at this point to fill the gaps in the town's hospital requirements left by the voluntary sector. The borough took responsibility for handling infectious diseases (which, though on the decline, were still a significant occasional menace), caring for the mentally ill, providing increased hospital provision for maternity cases and meeting the needs of the chronically ill. But Dingle's main contribution was

\footnotetext{
${ }^{68}$ South Tees-Side Hospital Management Committee, Souvenir of the commemoration of the centenary of West Lane Hospital, 1872-1972, Middlesbrough, South Tees-Side Hospital Management Committee, 1972; M Race, 'Writing the history of St. Luke's Hospital', Cleveland History, 1999, 76: 1-9; M Race, A century of care: a history of St. Luke's Hospital, Middlesbrough 1898-1998, Middlesbrough, 1999.

${ }^{69}$ Doyle, 'Urban government' op. cit., note 48 above, p. 290.

${ }^{70} \mathrm{M}$ Dagenais, I Maver and P-Y Saunier (eds.), Municipal services and employees in the modern
}

city: New historic approaches, Aldershot, Ashgate, 2003.

${ }^{71}$ Gorsky, 'Bristol', op. cit., note 28 above, section 4.4, 'The consolidation of municipal hospital policy'.

${ }^{72}$ Welshman, op. cit., note 30 above, p. 116, and B M Doyle, 'Mapping slums in a historic city: representing working-class communities in Edwardian Norwich', Planning Perspectives, 2001, 16: 47-65.

${ }^{73} \mathrm{G}$ Stout, 'Medical Officers of Health in nineteenth century Middlesbrough', Cleveland History, 2000, 78: 31-46; TA CB/M/H 14. 


\section{Barry M Doyle}

the appropriation of Holgate and the gradual development of a general hospital service in the 1930s. As noted above, the 1929 Local Government Act allowed the new Public Health Committees of county boroughs to "appropriate" the hospital provision transferred from the Board of Guardians to the Public Assistance Committee (PAC). ${ }^{74}$ Recent research by Levene, Powell and Stewart has shown that the speed and likelihood of appropriation varied across county boroughs, with factors such as the existence of discrete buildings, development of clinical specialisms or standards of accommodation, rather than party politics or the financial capacity of the borough, being of greatest importance. ${ }^{75}$ In Middlesbrough the borough appropriated immediately, a policy aided by the existence of a separate Poor Law Infirmary with a number of specialist departments and the fact that Dingle was already Administrative Superintendent at the hospital.

This municipal general hospital built on developments at the PLI by gradually expanding specialist and surgical treatments, improving the professionalism of the staff and reorganizing the arrangement of the accommodation to provide a clearer focus for the hospital's work. ${ }^{76}$ Admittedly, the patient profile did not change greatly, with the bulk of the patients still on very low incomes and still largely drawn from the labouring classes and those without access to the voluntary sector contributory schemes (unmarried women, wives and children of labourers) and those with diseases the voluntaries would not treatthe death rate remaining very high and the length of stay long. Thus, just after appropriation, the $\mathrm{MOH}$ noted that the death rate at Holgate of 23.6 per cent of total cases for 1932 "appears to be a big percentage but it cannot be compared with any ordinary general Hospital where, in certain establishments, a patient who is in any serious condition of illness is removed to a Hospital such as this and we have the last responsibility in the treatment of hopeless cases." 77 Although such a situation militated against any ambitions Holgate may have had to challenge the supremacy of the voluntary hospitals, Dingle was able to complete his reign by establishing a TB sanatorium at Poole (in a property donated by a leading town councillor) ${ }^{78}$ and when he retired in 1936 Middlesbrough's municipal provision ran to six institutions caring for a wide range of specialist and general- though not really surgical-conditions. ${ }^{79}$

\section{Municipal Integration}

As in Bristol, where the MOH reorganized the city's extensive existing borough and appropriated Poor Law institutions into a single service, municipal provision in Middlesbrough was effectively and efficiently integrated between the wars. Dingle used his

\footnotetext{
${ }^{74}$ See M Powell, 'Did politics matter? Municipal public health expenditure in the 1930s', Urban History, 1995, 22: 360-79, for details.

${ }^{75}$ Levene, Powell and Stewart, 'Municipal hospital care', op. cit., note 14 above.

${ }^{76}$ For the minutes of the hospital from 1930, see TA H/MG 1-9.

${ }^{77} \mathrm{MOH}$ report to Hospital committee, TA CB/M/H 14. The death rate for admissions
}

remained at between 20 and 25 per cent for the whole of the 1930s.

${ }^{78}$ Lillie, op. cit., note 36 above, pp. 192-3;

Mohan, 'Roots of regionalism', op. cit., note 26 above, p. 253.

${ }^{79}$ See Tees-Side Hospital Management Committee, Tees-Side hospitals: first report of the Tees-Side Hospital Management Committee, Middlesbrough, Tees-Side Hospital Management Committee, 1950. 


\section{Hospital Provision in Middlesbrough, 1918-1948}

different sites to create specialist centres-for example for maternity services-and to make more efficient use of resources, such as bringing children on to the Holgate site from Broomlands. ${ }^{80}$ Central to the policy of Dingle and his successors was a vision of municipal provision as complementary to that of the voluntary sector, with efficient organization, rather than grandiose projects at its core. ${ }^{81}$ It is conceivable that Middlesbrough's municipal doctors adopted this pragmatic position as a result of the rather straightened financial climate of the inter-war years in the town. The 1920s saw little building in the municipal sector-except for the small maternity hospital—whilst the capital projects of the 1930s were modest, and focused on reorganization rather than expansion. Thus, following appropriation, Broomlands children's hospital was closed and a children's hospital opened in a converted building on the Holgate site. Similarly, provision for a men's TB ward was fashioned out of existing accommodation and at a fairly minimal cost, whilst the Maternity Hospital was expanded to take all maternity cases. ${ }^{82}$

Local politicians seem to have been guided or constrained in their decisions by the Ministry of Health, whose inspectors invariably adopted a cautious approach on the grounds that what was really required was a complete rebuilding project but that was not possible at the present time due to economic weakness and uncertainty. Yet there is also evidence that the council could and did stand up to the ministry, for example, over the extension of the West Lane Infectious Diseases Hospital in $1934 .{ }^{83}$ Nor was Ministry caution as great as that found in places like Jarrow or South Shields, where Mohan suggests very severe economic crisis led central government to prevent capital projects. ${ }^{84}$ Yet it remains unclear whether the aims of local politicians were thwarted, whether there were voices calling for greater intervention or whether councillors largely shared the caution of the Ministry in the face of Dingle's grandiose and expensive plans. ${ }^{85}$ Overall, capital expenditure was concentrated on consolidation in the areas the municipality already controlled - maternity, children, infectious diseases, TB-whilst little was done to expand Holgate as a general hospital to compete with the voluntary sector. Indeed, unlike Bristol, where Gorsky sees municipal general provision offering a real challenge to the voluntary sector, in Middlesbrough this proved to be a low priority in the first half of the 1930s ${ }^{86}$ Following Dingle's retirement there were some changes and a more aggressive stance was taken towards the development of Holgate, yet even here progress was slow, with wartime prosperity weakening the pull of the General (as it was called from 1942) in the face of

\footnotetext{
80 'Survey of public health services. Report prepared by the Medical Officer of Health, May $29^{\text {th }} 1931$ ', TA CB/M/H 13.

${ }^{81}$ For the variety of approaches taken by municipal authorities, see Powell, 'Expanding service', op. cit., note 15 above, and the more recent work of Levene, Powell and Stewart, 'Municipal health expenditure' and 'Municipal hospital care', op. cit., note 14 above.

82 'Survey of public health services. Report prepared by the Medical Officer of Health, May $29^{\text {th }} 1931$ ', TA CB/M/H 13; Kitchen, op. cit., note 65 above; P Kitchen, Souvenir of the official opening . . . 22 $2^{\text {nd }}$ June 1935. Holgate Municipal
}

Hospital, (General) extension of the male surgical and tuberculosis wards, Middlesbrough, Middlesbrough Corporation, 1935.

${ }^{83}$ Minutes of the hospital committee, 19 Feb. 1934, TA CB/M/H 13.

${ }^{84}$ See Mohan, Planning, op. cit., note 8 above, pp. 40-2, 62-3.

${ }^{85}$ The author has been awarded a Wellcome Trust Grant to examine the 'Labour Party and Health Policy in Middlesbrough and Leeds, 1900-1950', in order to explore these themes further.

${ }^{86}$ Gorsky, 'Bristol', op. cit., note 28 above, section 4.3, 'The Local Government Act, 1929: a new ethos'. 


\section{Barry M Doyle}

buoyant income in the voluntary sector. ${ }^{87}$ Broadly, policy seems to have been determined by financial constraint, Ministry of Health dictat and the views of Dingle, rather than the active intervention of local politicians. ${ }^{88}$

The late 1920s and early 1930s saw the two voluntary hospitals develop much closer relations, treating each other's patients, sharing fund-raising events and supporting individual efforts, ${ }^{89}$ and holding discussions over developing joint services. Unlike Bristol, competition for funds was already being managed with the end to competitive appealsthe 1924 Mayor's appeal raising significant sums for both institutions. Active co-operation between the NOH and the NRI began in 1928 on the initiative of North Ormesby with attempts to develop a joint electro-therapy centre. ${ }^{90}$ Although unsuccessful, a consultative committee did follow, whilst an $\mathrm{NOH}$ representative noted that "if the meeting had no other result, the fact that it had been the means of developing the friendly relationship between the two Institutions much good would come of it."91 These early collaborations were not driven by financial imperatives-1927-29 were relatively good years for both institutions - but by a growing realization that the increasing demands of modern medicine would be met more effectively by rationalization. ${ }^{92}$ Furthermore, the social and economic geography of the town was beginning to change to the advantage of North Ormesby Hospital, whilst the municipalization of Holgate posed a further threat to the viability of North Riding Infirmary. ${ }^{93}$

This joint working was reinforced the following year when the two hospitals lobbied the corporation to be involved in the council's hospital planning in the wake of the 1929 Act. $^{94}$ Stalled by the corporation and embroiled in confusion about the status of the Carter Bequest Hospital (which was finally accepted as a voluntary by the others), ${ }^{95}$ by the time the meeting took place the $\mathrm{MOH}$ had already completed his planning. However, corporation and voluntary hospitals did meet to discuss a number of issues, including the development of specialist departments, a central clearing system for patients to place them in the most suitable institution, the co-ordination of existing specialist services, the development of co-ordinated laboratories to serve all institutions and general practitioners, and the reallocation of services currently the responsibility of the municipality which might be carried out by the other institutions. In these discussions it is clear the voluntary hospitals were keen to limit the extent to which the new general services of the municipality would impinge on their existing patients, whilst both sides were attempting to gain

\footnotetext{
${ }^{87}$ TA CB/M/H 14, 'Matters chatted about \& noted for future reference', Special reports of Medical Officer of Health, 1933-45.

${ }^{88}$ This analysis is close to that of the broader municipal picture offered by Levene, Powell and Stewart, 'Municipal hospital care', op. cit., note 14 above.

${ }^{89}$ NRI house committee minutes, 20 Dec. 1928 , TA H/MI (2) $1 / 8$.

${ }^{90} \mathrm{NOH}$ minute book, liaison sub-committee, 24 May 1929, TA H/NOR 1/23.

${ }^{91}$ TA H/NOR $1 / 23$, NOH council minutes, $18 / 12 / 28$
}

\footnotetext{
${ }^{92}$ S Sturdy and R Cooter, 'Science, scientific management, and the transformation of medicine in Britain c.1870-1950', Hist. Sci., 1998, 36: $1-47$.

${ }^{93}$ For the town's changing economic geography, see J W House and B Fullerton, Tees-side at mid-century: an industrial and economic survey, London, Macmillan, 1960.

${ }^{94}$ The 1929 Act required local authorities to consult the voluntary sector to achieve potential coordination. See Mohan, Planning, op. cit., note 8 above, p. 57.

${ }^{95} N E D G, 11$ July 1930.
} 


\section{Hospital Provision in Middlesbrough, 1918-1948}

access to new lucrative sources of funding without having to take on the burdensome work that the local authority was obliged to undertake. ${ }^{96}$

These negotiations were short-lived and led to no meaningful cooperation, in part because of financial and political crises at North Riding Infirmary, ${ }^{97}$ and in part because of the position of the MOH, Dr Dingle. Up to 1936, and especially in the years following the appropriation of the PLI, Dingle appears to have followed a policy of cooperation, not competition, with the voluntary sector. Throughout his period in office, he concentrated on developing the services that were specific to the local state, claiming in a memo of 1933 entitled 'Relations between voluntary and municipal hospitals' that co-ordination existed in practice as voluntary and public hospitals performed different functions:

The Voluntary Hospitals are established as the General Hospitals of the district while the Public Authority take on the responsibility for particular sections of hospital work, e.g. the duty of providing medical treatment for those unable to maintain themselves, to treat chronic cases, Infectious Diseases, Venereal Diseases, Tuberculosis, Maternity and School Children. ${ }^{98}$

He saw a number of areas in which further coordination was needed, including equipment and staffing, allocation of patients, training and placement of nurses, additional provision and consultant terms. However, more formalized cooperation may have been hindered in the early 1930s by the fact that he remained wedded to the idea that the Municipal Hospital and the Municipal Service should be at the centre of the town's hospital system on the lines suggested in the Dawson Report. Thus in 1933 he referred to the Dawson Report's advocacy of a Central Health Centre as the model, concluding that:

Should such a scheme be at any time conceivable, consideration might then be given to the desirability of creating the present Municipal Hospital into a Health or Clearing Centre around which all the other medical services would function. ${ }^{99}$

In his opinion, the voluntary hospitals would remain independent but subsidiary to a local state-run patient management system which would direct patients to the most appropriate institution for their condition. Whilst this may have been eminently sensible (and probably owed much to similar thinking within the powerful local Guild of Help, which attempted to manage welfare services on similar lines ${ }^{100}$ ) it was anathema to the management and medical staff of the voluntary hospitals. Thus it was not until 1936 and Dingle's retirement that close relations between municipal and voluntary sectors began to develop.

\section{Co-operation or Competition?}

Within the voluntary sector, the late 1920s saw the emergence of the "gentleman's agreement" between the NOH and the NRI (and later Stockton and Thornaby) to take each

${ }^{96}$ TA H/NOR 1/14, 'Report of Conference between the Middlesbrough Voluntary Hospitals Joint Consultative Committee and the Sanitary Committee, to which the whole of the members of the Middlesbrough Corporation were invited. Held on Thursday $18^{\text {th }}$ December 1930'.

${ }^{97}$ Doyle, 'Power', op. cit., note 53 above.

${ }^{98} \mathrm{TA} \mathrm{CB} / \mathrm{M} / \mathrm{H} 14$, 'Relations between voluntary and municipal hospitals', 31 May 1933,
Special reports of Medical Officer of Health, 1933-45.

${ }^{99}$ Ibid.

${ }^{100}$ For a general history of the Guild of Help, see $\mathrm{K}$ Laybourn, The Guild of Help and the changing face of Edwardian philanthropy, Lewiston, NY, Edwin Mellen, 1994. For links between hospital management and charitable managements, see Sturdy and Cooter, op. cit., note 92 above. 


\section{Barry M Doyle}

other's patients when necessary. Though generally successful and the key to developing a closer relationship with the corporation, there could be problems, especially when one hospital felt the system was being abused by contributors to one of the other institutions, as happened with workers at Dorman Long's Redcar plant in 1942. Yet it is clear that the existence and strength of contributory schemes, as in Sheffield, Norwich, Manchester and Birmingham, acted as a focus for joint working within the voluntary sector as well as reducing the impact, to some extent, of increased costs and demand in the 1930s. ${ }^{101}$ Furthermore, the economic crisis of the 1930s, the rapid rationalization of the iron and steel industry and severe managerial crisis at North Riding Infirmary in the early 1930s all contributed to a more conciliatory regime developing within the voluntary sector. ${ }^{102}$

More contentious, and the catalyst for an emerging rationalization of the town's hospital system, was the issue of voluntary hospital contributors being treated in the municipal hospital. This matter was raised in 1936 by Labour representatives on the Council, who complained that contributors to voluntary hospitals, admitted in emergency cases to the Municipal Hospital when the voluntaries were full, had to pay twice for their treatment. ${ }^{103}$ The problem brought voluntaries and the corporation together and led to an agreement that the voluntaries would meet the cost of their emergency patients admitted to Holgate. ${ }^{104}$ Although the Labour Party played a part in this development, politics in general-as in many towns-was not a major factor in the shaping of hospital policy. Middlesbrough was firmly in the hands of an anti-socialist coalition throughout the inter-war period and, as in Bristol, where there was coalition rule until 1937, health policy was generally progressive, whilst the contention that Labour made a difference is far from proved. ${ }^{105}$

This period also saw the emergence of real cooperation, especially the setting up of a radium centre for cancer patients at Holgate (supported by government grants) to which the voluntaries paid a flat rate of $£ 5.00$ for their patients. ${ }^{106}$ The rationalization of patients continued further during the war (a move that had nothing to do with the working of the EMS) when all agreed that the General could take any voluntary hospital contributor to be paid for by the voluntary hospital concerned. ${ }^{107}$ Seen as a way of both reducing the waiting

\footnotetext{
${ }^{101}$ Willis, op. cit., note 32 above; Cherry, 'Beyond national health insurance', op. cit., note 3 above; Pickstone, op. cit., note 24 above; Gorsky, 'Bristol', op. cit., note 28 above. In 1939 the $\mathrm{NOH}$ and the NRI, along with Stockton and Thornaby Hospital, were considering a move away from workplace collections to a central scheme, although the move had to be shelved due to the war. TA H/NOR $1 / 16$, 'Conference between representatives of North Riding Infirmary, North Ormesby Hospital and Stockton and Thornaby Hospital concerning the establishment of a contributory fund in Teesside', 7 Mar. 1939.

${ }^{102}$ Doyle, 'Power', op. cit., note 53 above.

${ }^{103} N E D G, 15$ Sept. 1936; TA H/NOR 1/15, 'Report of conference held between the representatives of the North Ormesby Hospital, North Riding Infirmary and the Hospitals Committee of the Middlesbrough Town Council', 19 Nov. 1936.
}

${ }^{104} \mathrm{TA}$ CB/M/C2/233, hospitals committee, 14 June 1938; TA H/NOR 1/16, Middlesbrough Hospitals Advisory Joint Committee (hereafter HAJC), 26 July 1938.

${ }^{105}$ S Davies and B Morley, County borough elections in England and Wales, 1919-1938: a comparative analysis, Aldershot, Ashgate, 2000, vol. 2, pp. 195-303; A Thorpe, " "One of the most backward areas of the country": the Labour party's grass roots in South West England, 1918-45', in M Worley (ed.), Labour's grass roots: essays on the activities and experiences of local Labour parties and members, 1918-45, Aldershot, Ashgate, 2005, pp. 216-39;

Powell, 'Politics', op. cit., note 74 above.

106 "Radium Commission visits Tees-side", NEDG, 6 Dec. 1938; TA H/NOR 1/16, Middlesbrough HAJC, 7 June 1939.

${ }^{107} \mathrm{TA} \mathrm{CB} / \mathrm{M} / \mathrm{H} 14$, 'Report upon the scheme for the treatment of contributors to the voluntary hospitals in 


\section{Hospital Provision in Middlesbrough, 1918-1948}

lists for the voluntaries (especially the NRI) and of raising the prestige of the General, it was a positive move and one that has so far been overlooked by historians of the region. ${ }^{108}$ However, it was not entirely successful for a number of reasons. Surgeons at the NRI attempted to abuse the system by exploring the possibility of using the facilities of the General to treat their voluntary hospital patients. Needless to say, the General refused to allow the surgeons access to their theatres, suggesting that "the obvious solution would be for the patients on that waiting list to be given the option of being admitted to the General Hospital under the existing agreement". 109

Of greater concern for the General was the tendency for the voluntaries to use it as a home for their undesirable patients. Thus, in September 1942, the MOH and the Medical Superintendent of the General noted that the Hospital should encourage surgeons from the $\mathrm{NOH}$ and the NRI to work there as consultants, as this would:

... encourage the entrance of acute work rather than the tendency to use it as a dumping ground for their objectionable cases. The latter state of affairs has happened and it is ruining the object which the Council had in mind to assist the General Hospital condition. At the same time it tends to threaten the prestige of the Municipal Hospital as a training school and subjects it to possible criticism from the General Nursing Council and to lower the status of its opportunities. ${ }^{110}$

A few months later, reviewing the operation of the new joint scheme, the Medical Superintendent and the $\mathrm{MOH}$ noted that, since the scheme came into operation in September, there had been an increase in the number of patients sent from the NOH and the NRI, though:

only about 5 of the cases sent since September can be described as acute cases, the others being obscure or semi-chronic cases which the Voluntary Hospitals did not normally wish to admit. So far as can be seen there has been no great attempt on the part of the Voluntary Hospitals to reduce their waiting lists by recourse to the provisions of the scheme ... careful watch will be kept by your officers on the position lest the type of case admitted militates against the improving status of the Municipal Hospital and its position as a Training School for nurses. ${ }^{111}$

Yet despite this slightly negative appraisal of the early workings of the scheme, it was undoubtedly a major step forward in setting up a structure for a more rational distribution of patients between the private and public sectors, which, along with the creation of an EMS hospital on the outskirts of Middlesbrough, opened up opportunities for further cooperation and patient exchange. ${ }^{112}$

A more significant development in pre-NHS moves towards a system in Middlesbrough came in 1938 when discussions took place about the possibilities of a merger between the

the Municipal Hospital', 9 Jan. 1943, Special reports of the Medical Officer of Health.

${ }^{108}$ There is no reference to this development in either Mansfield, op. cit., note 34 above, or Mohan, Planning, op. cit., note 8 above.

${ }^{109} \mathrm{TA} \mathrm{CB} / \mathrm{M} / \mathrm{H} \mathrm{14}$, 'Treatment of voluntary hospital contributors', Special reports of the Medical Officer of Health.

${ }^{110}$ TA CB/M/H 14, 'Matters chatted about \& noted for future reference', Special reports of the Medical Officer of Health.
${ }^{111} \mathrm{TA} \mathrm{CB} / \mathrm{M} / \mathrm{H} 14$, 'Relations between voluntary and municipal hospitals', 31 May 1943, Special reports of Medical Officer of Health, 1933-45.

${ }^{112}$ Royal Commission on the Historical Monuments of England, 'Historic buildings report: Hemlington hospital', unpublished report of the RCHME, York, 1993; TA CB/M/H 14, 'Health services', 16 Oct. 1942, Special reports of the Medical Officer of Health; Ministry of Health, Hospital survey, op. cit., note 33 above, p. 70 . 


\section{Barry M Doyle}

NRI and the NOH and the building of a new hospital on a new site. ${ }^{113}$ However, though the NRI approved of the proposal put forward by Mr Orde (Secretary of the British Hospitals Association), North Ormesby rejected it on a number of grounds, including the belief that small hospitals were cheaper to run than large ones, that a new 400 bed hospital would cost around $£ 500,000$ to build, a sum unlikely to be raised in the town, and on the fact that many of the buildings at North Ormesby were new or relatively new, that $£ 75,000$ had been raised and spent on the institution in the preceding fifteen years and therefore the extension of the North Ormesby site was the logical way forward. Most significantly, however, the medical and surgical staff had rejected the idea outright (though why is not clear). ${ }^{114}$ The plan was dropped and the war ensured that the subject was not raised again until the later 1940s. Nevertheless, the incident did show that progress was being made towards a more rational and efficient hospital service in the town, and the $\mathrm{NOH}$ did make clear that they were "in favour of the fullest possible cooperation in every way with the NRI". ${ }^{115}$ Mohan and Mansfield have seen the failure of this move towards a single site and single hospital as a sign of the parochialism of the $\mathrm{NOH}$ and the overall weakness of the voluntary system. ${ }^{116}$ But it needs to be considered in the light of a number of local elements, not least the weakness - financially and politically — of the NRI and the real strength of the $\mathrm{NOH}$, which was benefiting not only from sound finances at the time but also from the movement of industry down-river. ${ }^{117}$ Furthermore, it is worth noting that it took the NHS fifty-five years to deliver a single site hospital to Middlesbrough, the completion of which occurred in 2003. ${ }^{118}$

Although this clearly was a set-back for joint working, in other areas steps forward were being made. In 1938-9 the voluntary hospitals agreed a common scale for nurses pay, and both moved towards a 48-hour week by $1940 .{ }^{119}$ Regional organization occurred through both the BHA and the development of a North-East Regional Advisory Committee. ${ }^{120}$ Finally, through all these agencies, but especially the Middlesbrough Joint Advisory Committee, plans were beginning to emerge for the formation of a specialist eye unit in the town. ${ }^{121}$ This was supported by the local consultant, A E P Parker, and by many of the leading contributors, especially the workers at Dorman Long, who provided around one-third of North Riding's income. By 1944 discussions were revolving around acquiring

\footnotetext{
${ }^{113}$ TA H/NOR 1/16, 'Report of a joint meeting of representatives of the North Ormesby Hospital and the North Riding Infirmary ... 4 August 1937'; NEDG, 5 Aug. 1937; NEDG, 14 Apr. 1938.

${ }^{114}$ The reasoning of the NOH Council was set out in a letter to Sir Francis Samuelson on 15 Nov. 1938 and reported in NOH Council Minutes, 28 Nov. 1938, TA H/NOR 1/16. For the terse note of rejection of the scheme by the medical staff see TA H/NOR $1 / 16$, 'Meeting of the hon. medical and surgical staff ... $21^{\text {st }}$ September 1938 to consider the Orde Report and the recommendations of the joint report'. See also TA H/NOR 1/16, Middlesbrough HAJC, 7 June 1939, and $N E D G, 8$ June 1939.

${ }^{115}$ Gerald Cochrane to Sir Francis Samuelson, 15 Nov. 1938 in TA H/NOR 1/16, NOH Council Minutes, 28 Nov. 1938.
}

\footnotetext{
${ }^{116}$ Mohan, Planning, op. cit., note 8 above, p. 54; Mansfield, op. cit., note 34 above, p. 54.

${ }^{117}$ Doyle, 'Power', op. cit., note 53 above; North, op. cit., note 36 above.

${ }^{118}$ Doyle, Hospitals, op. cit., note 33 above, p. 19; Mohan, Planning, op. cit., note 8 above, pp. 106-7, for the politics of building decisions in the 1950s.

${ }^{119}$ TA H/NOR 1/16, Liaison Committee, 5 Aug. 1938

${ }^{120}$ Northern Echo, 18 May 1940; NEDG, 27 Nov. 1940; TA H/NOR 1/17, NOH Minutes, 28 Nov. 1940.

${ }^{121}$ TA H/NOR $1 / 17$, NOH Council Minutes, Aug. 1942; Middlesbrough HAJC, 27 Apr. 1943; Liaison Committee, 19 Oct. 1943. Mansfield suggests that $\mathrm{NOH}$ Council had rejected a joint eye clinic in
} 


\section{Hospital Provision in Middlesbrough, 1918-1948}

a new site for the treatment of all eye cases, the setting up of a unit at the General (rejected at the time until after the war) or the setting up of a local clinic by the Priestman and Sunderland Eye Infirmary with the object of taking the consultants to the patients and not the other way round. ${ }^{122}$ Clearly the rational development of specialist services was being debated and arguably it was the impending intervention of the state-with the publication of the White Paper on post-war health services-which stalled a decision.

\section{Conclusion}

In 1948 the voluntary and municipal providers of Middlesbrough handed over nine hospitals to the new National Health Service, including acute, chronic, maternity, infectious disease and mental health institutions. The buildings varied in quality, were dispersed across a wide geographical area, a number were too small and there were problems with staff skill levels and equipment. Furthermore, Middlesbrough remained some way from a rationalized, efficient hospital service, with divisions and duplication remaining within and between the sectors. ${ }^{123}$ Yet it had clearly moved a long way in twenty-five years and especially from 1936 onwards. An efficient division of labour between the voluntary and municipal sector had developed under Dingle, which saw the former committed to delivering acute, specialist, surgical, and accident and emergency services whilst the local state expanded its provision of non-acute, maternity, mental health and infectious disease cover. In the later 1930s, and especially during the Second World War, positive steps were taken both to extend municipal activity with the improvement of acute departments at the General and to develop joint working within and between the public and private sectors. In contrast to Bristol, the existence of contributory workplace schemes ensured increasingly close relations between the main voluntary hospitals and probably weakened the ability of the municipal general hospital to expand its acute work. ${ }^{124}$ Overall, by the mid-1940s the town could boast hospital provision that addressed all of the key health problems which had built up over the previous one hundred years and provided an adequate service, often free at the point of delivery, to most of the population. Moreover, this expansion and integration was achieved without a central medical school, for whilst Newcastle was important regionally, its impact in the Tees Valley sub-region was minimal - a situation very similar to that in Preston. ${ }^{125}$ Without the patronage, independence, specialists and income of a teaching hospital to focus upon, Middlesbrough hospitals were obliged to work their way to integration collectively and what is apparent is how much had been achieved by 1946 with little or no external direction. Yet too often historians have approached pre-NHS urban hospital systems from a maximalist position, frequently influenced by the highly critical but partial views of Ministry of Health and

1942, but if they did they had changed their mind by the following year. Mansfield, op. cit., note 34 above, p. 60.

${ }^{122}$ TA H/NOR 1/17, Liaison Committee, 15 Mar. 1944.

${ }^{123}$ Ministry of Health, Hospital survey, op. cit., note 33 above; Tees-Side HMC,
Tees-Side hospitals, op. cit., note 79 above.

${ }^{124}$ Gorsky, 'Bristol', op. cit., note 28 above, ch. 6, 'Conclusion'.

${ }^{125}$ Mohan, Planning, op. cit., note 8 above; Pickstone, op. cit., note 24 above, pp. 262, 266. 


\section{Barry M Doyle}

Nuffield inspectors who painted a deliberately bleak picture of existing provision. ${ }^{126}$ However, by working from the records of the hospitals and the municipal authorities within the locality, it has been possible to build a more optimistic picture which illustrates the good relations between all hospital providers by the early 1940s and suggests that an integrated and modernized mixed economy hospital system could have been developed in the prosperity of post-war Britain.

${ }^{126}$ For a clear critique of this position, see Pickstone, op. cit., note 24 above, p. 266. 